Proc. Estonian Acad. Sci. Geol., 2001, 50, 3, 149-173

\title{
DESCRIPTION OF THE TYPE SECTION, CYCLICITY, AND CORRELATION OF THE RIKSU FORMATION (WENLOCK, ESTONIA)
}

\author{
Heldur NESTOR, Rein EINASTO, Viiu NESTOR, Tiiu MÄRSS, \\ and Viive VIIRA \\ Institute of Geology, Tallinn Technical University, Estonia pst. 7, 10143 Tallinn, Estonia; \\ hnestor@gi.ee
}

Received 28 February 2001, in revised form 6 June 2001

\begin{abstract}
The lower Wenlock to middle Ludlow section of the Riksu drill core from western Saaremaa Island (Estonia), including the stratotype interval of the Riksu Formation (Jaagarahu Regional Stage, middle Wenlock) is described. The lower boundary of the formation is redefined in the type section and is placed on the top of the Paramaja Member of the Jaani Formation. Three subunits, the Lower, Middle, and Upper Riksu beds, are established. An intricate multistage sedimentary cyclicity of the Riksu Formation is described; the meso-, submeso-, mini-, and subminicycles are provisionally equated with 400, 100, 41, and 23 Ka Milankovitch cycles, respectively. The Riksu Formation is roughly correlated with its lateral equivalents - the Jaagarahu, Muhu, and Jamaja formations in Estonia, and with the successive upper Högklint, Tofta (Kopparsvik), and Slite beds on Gotland.
\end{abstract}

Key words: correlation, cyclicity, type section, Estonia, Wenlock, Silurian.

\section{INTRODUCTION}

In the belt of outcrops on northern Saaremaa Island, Estonia, the middle part of the Wenlock Series is represented by the Jaagarahu Formation, the eponymous lithostratigraphical unit of the Jaagarahu Regional Stage (Aaloe et al. 1976; Grigelis 1978; Kaljo 1987; H. Nestor 1995a, 1997) (Fig. 1). The Jaagarahu Formation consists of various biohermal, coral-stromatoporoid, and bioclastic limestones (mainly skeletal and pelletal grainstones), cyclically alternating with laminate (Eurypterus-) and bioturbated (mottled) argillaceous dolostones. According to the facies-sedimentological model by H. Nestor \& Einasto (1977), these rocks were formed, respectively, in the shoal and lagoonal facies zones of the Baltic Palaeobasin. Eastwards, the Jaagarahu Formation is replaced by comparatively 


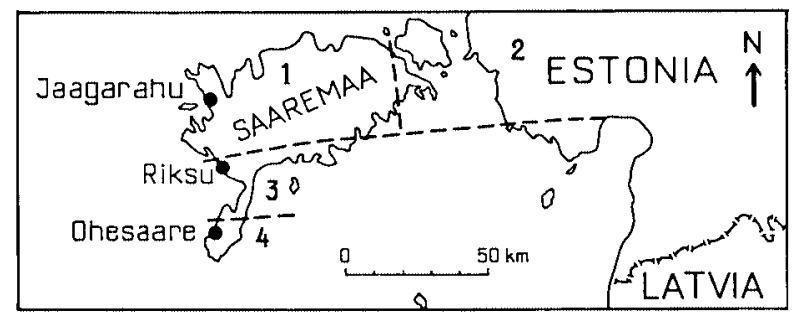

Fig. 1. Location of stratotypes and lateral extent of the formations of the Jaagarahu Regional Stage. 1, Jaagarahu Fm.; 2, Muhu Fm.; 3, Riksu Fm.; 4, Jamaja Fm.

monotonous, platy, secondary dolostones and bioturbated, argillaceous, dolomitized wackestones of the Muhu Formation, interpreted as deposits of the restricted shelf or the lagoonal facies belt (V. Nestor \& Einasto 1997). The formation spreads on Muhu Island and in western mainland Estonia. The lower part of the Muhu Formation contains large massive, dolomitized carbonate mounds distinguished as the Kesselaid Member.

For a long time it was supposed that in a southerly, offshore direction the shoaly limestones and lagoonal dolostones of the Jaagarahu and Muhu formations were replaced by the nodular, biomicritic, and argillaceous limestones of the Sõrve Formation (Aaloe 1970). However, V. Nestor (1984) and V. Nestor \& H. Nestor (1991) proved that actually the Sorrve Formation lies stratigraphically higher in the succession than the Jaagarahu Formation and a thick pile of marlstones in southwestern Saaremaa (Sõrve Peninsula), now called the Jamaja Formation (Kaljo 1987), correlates with the Jaagarahu Formation. H. Nestor \& Einasto (1977) treated these marlstones as deposits of the transition (slope) facies zone. The missing link between the shoaly facies of the Jaagarahu Formation and the transitional marlstones of the Jamaja Formation, that is, contemporaneous deposits of the open shelf facies zone, stayed unknown until 1988, when a borehole was drilled near Lake Riksu in western Saaremaa about halfway between Jaagarahu and Ohesaare (Fig. 1), where, respectively, type sections of the Jaagarahu and Jamaja formations are located (H. Nestor 1993). In the interval of 80.4-127.4 m of this core, a $47 \mathrm{~m}$ thick complex of nodular, argillaceous limestones and marlstones was recorded. The complex is externally very similar to the Sorve Formation but lies lower in the stratigraphical succession, corresponding to the level of the Jaagarahu and Jamaja formations. This unit was previously established and briefly defined as the Riksu Formation (H. Nestor 1995a, 1997), but an adequate description of the stratotype section is published for the first time here.

The beds under- and overlying the Riksu Formation in the stratotype section do not differ considerably from contemporaneous strata in the outcrop belt of northern Saaremaa, thus the same lithostratigraphical terminology can be applied to the Riksu drill core except for the strata belonging to the Riksu Formation. 
This was the reason why the base of the Riksu Formation, preliminarily defined at a level of $144.7 \mathrm{~m}$ (H. Nestor 1993, 1995a; Perens 1995), was later shifted upwards to the top of the Paramaja Member of the Jaani Formation at a depth of $127.4 \mathrm{~m}$ (H. Nestor 1997, fig. 69).

The Riksu core section plays a rather important role in the correlation of shallow-water carbonate and deeper-water argillaceous rocks of Wenlock to Ludlow age. Therefore the present study gives a short picture of the whole bedrock sequence and faunal succession of the core, including the macrolithological description (by R. Einasto and H. Nestor); identification and biostratigraphical analysis of corals and stromatoporoids (H. Nestor), chitinozoans (V. Nestor), conodonts (V. Viira), and vertebrates (T. Märss). Rare brachiopods were identified by M. Rubel.

\section{STRATIGRAPHICAL SEQUENCE}

The Riksu 803 borehole on the west coast of Saaremaa Island near Lake Riksu was drilled in 1988 in the course of the hydrogeological mapping of the territory. The core, $90 \mathrm{~mm}$ in diameter, is stored at Särghaua field station of the Institute of Geology at Tallinn Technical University. Below, the generalized description of the bedrock section is given (see Fig. 2 for $\log$ ). Depth intervals start from the orifice of the borehole; thicknesses of the intervals are shown in parentheses.

\section{Paadla Formation}

19.8-22.4 (2.6) m. Uduvere Beds (lowermost part). Wavy-bedded, skeletal grain- to wackestones (packstone dominating) with numerous rounded skeletons of stromatoporoids, corals, and rare calcareous algae, oncolites, gastropods, and lepertitide ostracodes.

22.4-27.6 (5.2) m. Himmiste Beds. Medium- to thick-bedded, microlaminated, argillaceous dolostones with a layer of skeletal-pelletal grainstone with stromatoporoids, corals, oncolites, and calcareous algae in its middle part.

27.6-39.8 (12.2) m. Sauvere Beds. Nodular to wavy-bedded, argillaceous, bioclastic limestones (packstone to wackestone). In the lower part $(33.5-39.8 \mathrm{~m})$ the rock is more argillaceous, with many discontinuity surfaces (hardgrounds), abundant pyritized bioclasts, burrows, and rare fine-grained, tempestite interlayers.

\section{Rootsiküla Formation}

39.8-47.5 (7.7) m. Soeginina Beds. Medium-bedded, partly porous, platy dolostones of variable texture and content. The interval contains some interlayers of laminate, Eurypterus-, and bioturbated, pyrite-mottled dolostones forming the upper part of lower-rank sedimentary cyclites (minicyclites), as well as thin, pelletal and coquinoid (gastropod, bivalve, ostracode) intercalations in their lower part. Discontinuity surfaces mark the boundaries of minicyclites.

47.5-54.6 (7.1) m. Vesiku Beds. The unit consists of cyclically interlayering dolostones and dolomitized limestones forming minicyclites. The lower part of 
each minicyclite consists of thin-bedded, dolomitized, litho-bioclastic grain- and floatstones intercalated with biomicritic and micritic limestones with pyritized discontinuity surfaces. The skeletal particles of grainstone are well-rounded. The upper part of minicyclites is represented by laminate, argillaceous, Eurypterusdolomite with frequent eroded bedding planes, and some levels containing stratified stromatolites and brecciated dolostones. In the uppermost minicyclite (47.5$50.8 \mathrm{~m}$ ) the primary, Eurypterus-dolomite prevails, while in lower minicyclites $(50.8-52.7$ and $52.7-54.6 \mathrm{~m})$ the basal, secondary-dolostone part is thicker.

54.6-58.5 (3.9) m. Kuusnõmme Beds. Wavy- to horizontal-bedded, lithobioclastic, dolomitic floatstone to skeletal wackestone. Among skeletal particles leperditide ostracodes prevail. Thin coquinoid (ostracode) and pelletal-skeletal intercalations occur. The rock is variably argillaceous and often bioturbated. The unit is capped by the layers of Eurypterus- and mottled dolostones, and it corresponds to the basal part of a mesocyclite (Fig. 2).

58.5-65.7 (7.2) m. Viita Beds. The upper part of the interval $(58.5-62.0 \mathrm{~m})$ is represented by laminate, argillaceous, Eurypterus-dolostone with rare, thin intercalations of micritic, and litho-bioclastic, dolomitized limestones consisting of the particles of bryozoans, ostracodes, and smooth-test tentaculites. The lower part of the unit $(62.0-65.7 \mathrm{~m})$ consists of interlayering argillaceous dolomicrite and dolomitized, litho-bioclastic floatstone to argillaceous wackestone with frequent pyritized discontinuity surfaces.

Jaagarahu Formation (overlapping tongue)

65.7-73.7 (8.0) m. Light grey, massive, mottled, limy dolomicrite with abundant specimens of the tabulate coral Riphaeolites $\mathrm{cf}$. lamelliformis. In the middle part $(68.2-69.4 \mathrm{~m})$ the rock is porous, with relict biomicritic texture. The basal part $(69.4-73.7 \mathrm{~m})$ contains numerous rounded skeletons of tabulates and stromatoporoids. The interval forms a mesocyclite.

Fig. 2. Stratigraphy, lithological log, and facies curve of the bedrock sequence of the Riksu core. Legend: 1, Eurypterus-dolostone; 2, argillaceous dolostone; 3, bioturbated dolostone; 4, micritic limestone (a) and dolostone (b); 5, biomicritic limestone: (a) fine-grained, (b) varigrained; 6, varigrained grainstone; 7, grainstone: (a) fine-grained, (b) coarse-grained; 8, silty dolostone; 9, nodular biomicritic limestone; 10, nodular argillaceous limestone; 11, nodular limestone with thicker marlstone intercalations; 12, limestone/marlstone intercalation; 13, calcareous marlstone; 14, argillaceous marlstone; 15, discontinuity surfaces: (a) even, (b) rugged, (c) with hiatus; 16, (a) mudcracks, (b) ripple-marks; 17, pebbles; 18, angular lithoclasts; 19, oolite; 20, pyrite mottles; 21, burrows; 22, coarse, pyritized burrows; 23, stromatoporoids; 24, rounded stromatoporoids; 25 , massive tabulates; 26 , dendroid tabulates; 27 , encrusting tabulates; 28 , rugose corals; 29 , coquina; 30, brachiopods; 31 , trilobites; 32 , pelmatozoans; 33 , bryozoans; 34 , cephalopods; 35 , gastropods; 36, bivalves; 37, ostracodes; 38, tentaculites; 39, eurypterids; 40, calcareous algae; 41, nodular stromatolites; 42, stratiform stromatolites; 43, oncolites; 44, tempestites. Stratigraphical indices: $\mathrm{K}_{2} \mathrm{U}$, Uduvere Beds; $\mathrm{K}_{2} \mathrm{H}$, Himmiste Beds; $\mathrm{K}_{2} \mathrm{~S}$, Sauvere Beds; $\mathrm{K}_{1} \mathrm{~S}$, Soeginina Beds; $\mathrm{K}_{1} \mathrm{Vs}$, Vesiku Beds; $K_{1} K$, Kuusnõmme Beds; $K_{1} V t$, Viita Beds; $J_{1} P$, Paramaja Member; $J_{1} N$, Ninase Member; $\mathrm{J}_{1} \mathrm{M}$, Mustjala Member. 


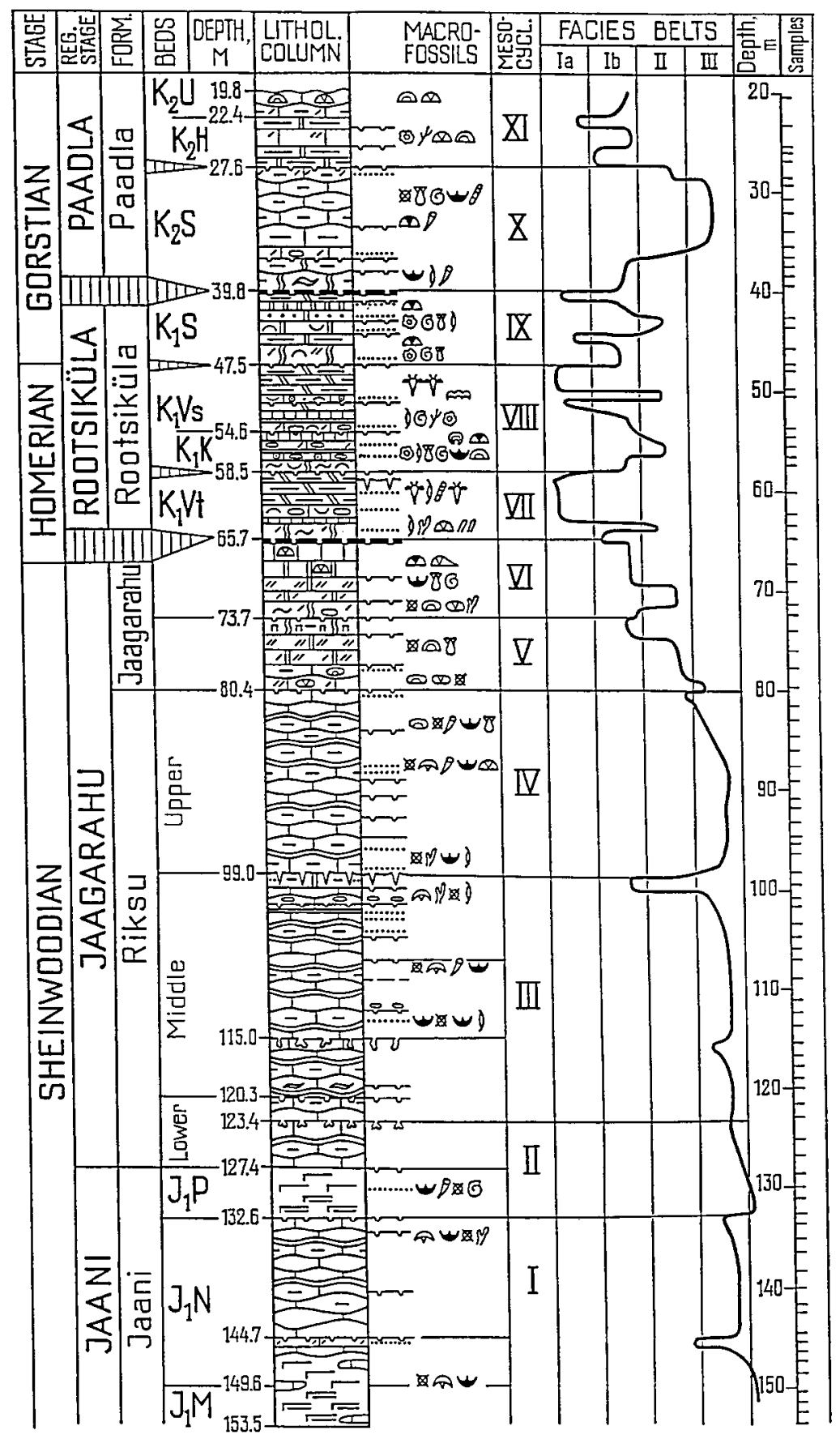

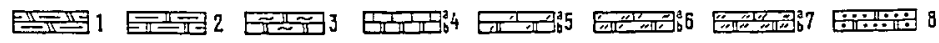

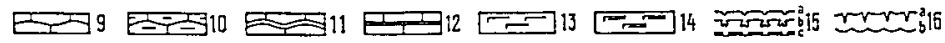

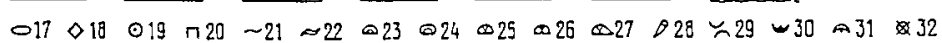

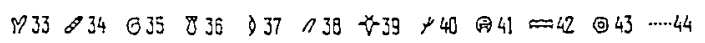


73.1-80.4 (7.3) m. Medium- to thick-bedded dolomitic limestone consisting of several sedimentary minicyclites. The lower part of a minicyclite is represented by fine-grained, often bioturbated, argillaceous pack- to wackestones with mottles of dispersed pyrite; upper - by variable sparitic limestones from varigrained floatstone to well-sorted, pyritized, fine-grained grainstone, sometimes with normally graded bedding. The proportion of grainstone gradually increases upwards. Skeletal material consists mainly of pelmatozoans particles; rounded remains of corals, stromatoporoids, and bivalves (Megalomus? sp.) are quite common, particularly in coarser grainstones. The interval corresponds to a mesocyclite.

\section{Riksu Formation}

80.4-99.0 (18.6) m. Upper Beds. Nodular to wavy-bedded, biomicritic limestones (packstone to wackestone) with undulating intercalations $(1-5 \mathrm{~cm}$ thick) and some thicker layers (up to $50 \mathrm{~cm}$ ) of calcareous or argillaceous marlstone. The rock contains pyritized skeletal particles of pelmatozoans, brachiopods, and trilobites, burrows of deposit feeders, and sporadically, pyritized lithoclasts.

The alternation of rock types displays complicated, multistage cyclicity; the low-rank minicyclites are best expressed. The lower part of each minicyclite consists of a $20-50 \mathrm{~cm}$ thick layer of marlstone or argillaceous limestone, succeeded by nodular to wavy-bedded, varigrained, skeletal packstone or wackestone with uneven, pyritized discontinuity surfaces (hardgrounds), and tempestite interlayers of fine-grained grainstone (sometimes with normally graded bedding). A minicyclite is capped by seminodular (knobby-bedded) layer(s) of packstone with rounded, pyritized skeletal particles and scattered lithoclasts. The minicyclites are bounded by uneven, pyritized hardgrounds occurring at depths of 82.5, 84.5, 86.2, 88.1, 89.4, 91.1, 93.2, 95.6, 98.0, and $99.0 \mathrm{~m}$ (Fig. 3). Minicyclites are unevenly developed. Upwards in the sequence, the role of marlstone layers and intercalations decreases and cyclicity becomes less distinct. The minicyclites form four submesocyclites (Fig. 3) and are subdivided into still lower-rank, obscure, incomplete subminicyclites.

Fig. 3. Lithological $\log$ and cyclites of the Riksu and Jaani formations in the Riksu core. Legend: 1, limestone; 2, dolostone; 3, micritic limestone; 4, argillaceous limestone; 5, fine-nodular limestone; 6 , medium-nodular limestone; 7, coarse-nodular limestone; 8 , knobby bedding; 9 , varigrained biomicritic limestone; 10, fine grainstone; 11, coarse grainstone; 12, marlstone intercalations; 13 , calcareous marlstone with limestone nodules; 14, argillaceous marlstone; 15 , dolomite marlstone; 16, dolomitic marlstone; 17, burrowed erosional surface; 18, rugged hardground; 19, even hardground with borings; 20, weak discontinuity surface; 21, bioturbated surface; 22, ash layer; 23, coarse, pyritized burrows; 24, fine burrows; 25, pebbles; 26, pyritized pebbles; 27, pyritized bioclasts; 28, coquina; 29, tabulate corals; 30 , stromatoporoids; 31 , rounded skeletons; 32 , brachiopods; 33, trilobites; 34, rugose corals; 35, bryozoans; 36, pelmatozoans; 37, bivalves; 38, gastropods; 39, cephalopods; 40, ostracodes; 41, oncolites; 42, stromatolites; 43, tempestite layer; 44, submacrocyclite boundary; 45 , mesocyclite boundary; 46, submesocyclite boundary; 47, minicyclite boundary; 48 , subminicyclite boundary. 

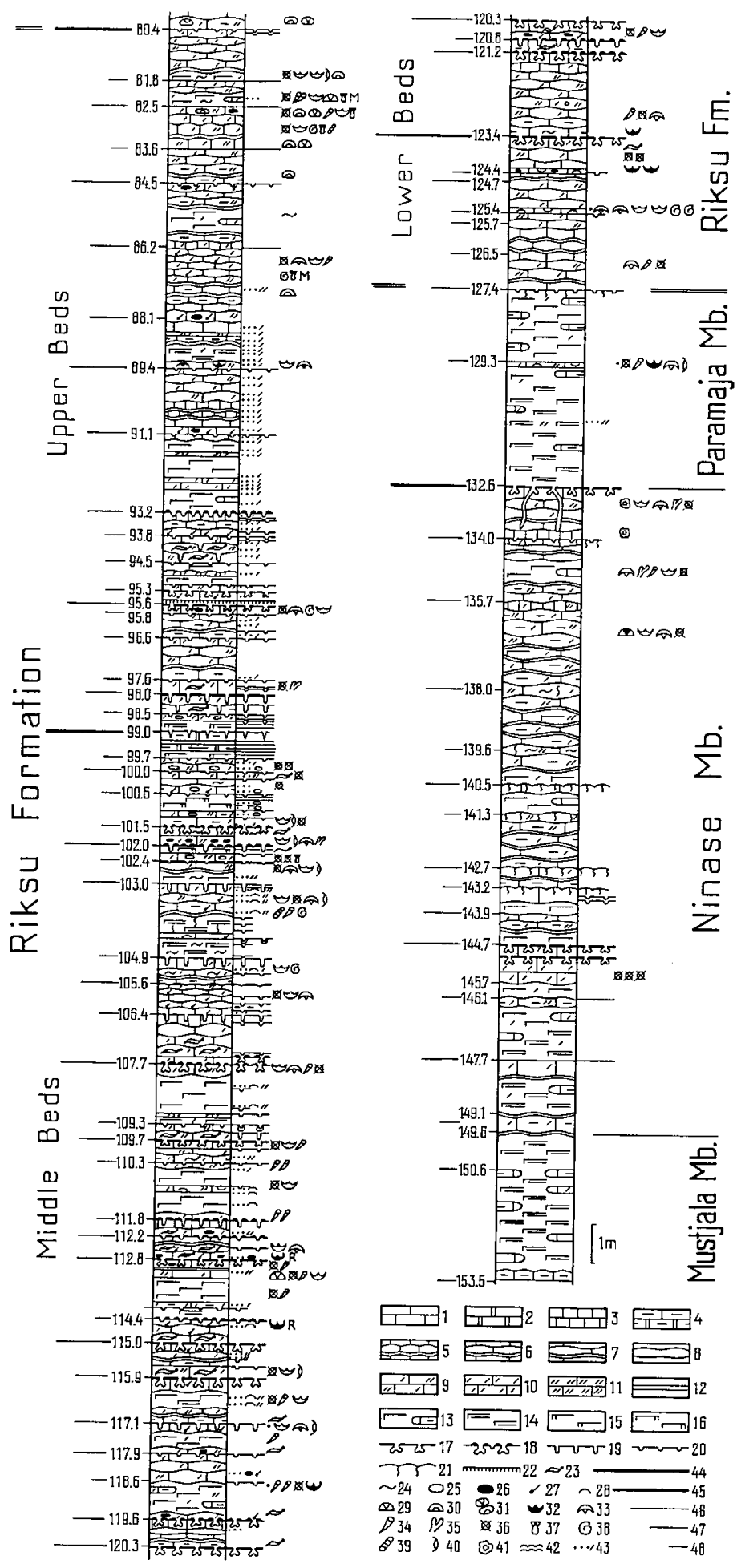

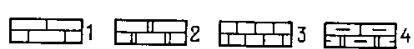

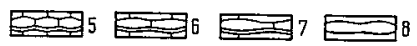

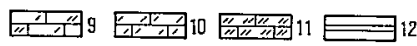

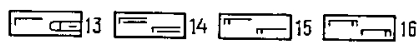
$25017-252518$ v vणv19 vov? Tr 21 mmmmm $22 \approx 23 \longrightarrow 44$ $\sim 24 \quad 025 \quad-26 \quad 27-28-45$

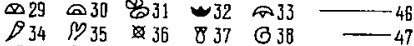

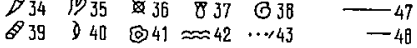


Pyritized hardgrounds and thin tempestite interlayers are common only in the lower half of the described interval beginning from $88.0 \mathrm{~m}$. The lowermost part of the unit $(93.8-99.0 \mathrm{~m})$ is distinguished by the presence of abundant deep burrows, often fully penetrating the limestone layers. A $10 \mathrm{~cm}$ thick bentonitelike interlayer of calcareous clay occurs at $95.5-95.6 \mathrm{~m}$. A hardground with very deep (up to $20 \mathrm{~cm}$ ), broad cavities lies at $98.0 \mathrm{~m}$. Another hardground, with wide, cracked cavities resembling mudcracks, marks the base of the described unit. The unit forms a mesocyclite.

99.0-120.3 (21.3) m. Middle Beds. An analogous to the Upper Beds cyclic alternation of nodular to wavy-bedded, biomicritic limestones and marlstones. However, argillaceous rocks do not lie at the very base of a minicyclite but are usually underlain by a $0.2-0.6 \mathrm{~m}$ thick layer of nodular, argillaceous, bioturbated, skeletal packstone or wackestone with characteristic stout burrows fringed by dispersed pyrite halo. The boundaries of minicyclites are represented by uneven pyritized hardgrounds with deep burrows at 100.0, 102.0, 105.6, 107.7, 109.7, $112.8,115.0,115.9,117.1,117.9,119.6$, and $120.3 \mathrm{~m}$ (Fig. 3). The elements of a minicyclite are unequally developed in different parts of the unit. In the lower part $(115.0-120.3 \mathrm{~m})$ all three minicyclite elements are more or less equally developed; in the middle part (107.7-115.0 m) the upper, most calcareous, seminodular (knobby-bedded) part of a minicyclite is reduced; in the upper part (99.0-107.7 m) alternation of rock types becomes variable and more irregular, some elements of a minicyclite may be totally lacking, most often the lower, bioturbated, or the middle, marly part of it. The lower part may be replaced by a layer of unsorted packstone to floatstone with pyritized litho- and bioclasts. Shallower-water features (tempestite interlayers, discontinuity surfaces) are very frequent. The topmost layer (99.0-99.7 m) of the described interval is represented by a microlaminated, silty, argillaceous dolostone with possible mudcracks on its upper surface (see above).

120.3-127.4 (7.1) m. Lower Beds. Nodular to wavy-bedded biomicritic limestones with thin marlstone intercalations. This interval is the most calcareous in the Riksu Formation; the average limestone/marlstone ratio is $4 / 1$, decreasing in both directions from a prominent erosional surface at a level of $123.4 \mathrm{~m}$. This surface designates a higher-rank (mesocyclite and submacrocyclite) boundary, which constitutes a breaking point in a shallowing upwards trend of development in the sequence. The erosional surface is strongly pyritized, with deep (up to $30 \mathrm{~cm}$ ), fissure-like pockets. Immediately below the erosional surface skeletal particles are well-sorted, fine-grained, and rounded, above the surface - badlysorted. The low-rank minicyclicity is less distinct and of lower contrast than in the overlying strata. Tempestite interlayers are lacking. A series of uneven, pyritized discontinuity surfaces with broad, tortuous pockets occurs at the top of the described interval. The base of the unit forms a sharp lithological boundary with signs of pyritization. The boundaries of the described unit do not coincide with those of the mesocyclites. 


\begin{abstract}
Jaani Formation
127.4-132.6 (5.2) m. Paramaja Member. Massive to wavy-bedded marlstone with lenticular nodules and discontinuous interlayers of argillaceous wackestone. The frequency of limestone nodules and interlayers gradually decreases downwards in the sequence. In the upper part of the interval (127.4-130.2 m) the marlstone is calcareous, in the lower part $(130.2-132.6 \mathrm{~m})$ argillaceous. The marlstone contains fine burrows of sediment feeders, and scattered, light bioclasts of brachiopods, pelmatozoans, and rugose corals. At the lower boundary occurs a pyritized hardground with wide, deep, tortuous cavities, which forms a boundary of mesocyclites.

132.6-149.6 (17.0) m. Ninase Member. Vague cyclical alternation of nodular, argillaceous, micritic to biomicritic limestone (wackestone) with bioturbated calcareous marlstone. The marlstone occurs in the form of thin, undulating intercalations and thicker layers containing limestone nodules. Transition from marl to limestone is gradual, i.e. the marlstone/limestone minicyclites are symmetrical. Only one grainstone interlayer, represented by almost massive, fine-grained grainstone occurs at $144.7-145.7 \mathrm{~m}$. Two conspicuous pyritized hardgrounds with deep cavities are observed just above the grainstone layer; these mark the boundary of submesocyclites. The lower contact of the member is lithologically gradual.

149.6-153.5 (3.9+) m. Mustjala Member (uppermost part). Argillaceous marlstone with scattered nodules and a few layers (up to $50 \mathrm{~cm}$ ) of nodular, argillaceous, micritic limestone with rare bioclasts of brachiopods, trilobites, and pelmatozoans.
\end{abstract}

\title{
CYCLICITY OF THE RIKSU FORMATION
}

The Riksu Formation belongs to a macrocyclite embracing the Adavere, Jaani, and Jaagarahu regional stages roughly corresponding to the Telychian and Sheinwoodian of the global standard. The macrocyclite is bounded by subregional unconformities (H. Nestor \& Einasto 1997, p. 196) and corresponds to a sediment sequence. The Riksu Formation coincides with the middle part of the long, regressive phase of this macrocyclite and is characterized by a complicated multistage cyclicity superimposed on the general shallowing trend of development. The facies curve in Fig. 2 shows that in the type section the Riksu Formation was almost completely formed within the open shelf facies zone (zone III), regardless of its conspicuous low-rank cyclicity.

At the same time, the underlying Jaani Formation is characterized by a simple, contrasting mesocyclic alternation of marlstones of the fourth (Mustjala and Paramaja members) and nodular biomicritic limestones of the third (Ninase Member) facies zones (Fig. 2). However, the lower boundary of the Riksu Formation does not coincide with the base of a mesocyclite but with a sharp lithological boundary in the middle of mesocyclite II at a depth of $127.4 \mathrm{~m}$ (Fig. 2), where the carbonate content increases markedly. Such a sharp lithological 
change is observable in the extensive distribution area of the Jaagarahu, Riksu, and Muhu formations and has traditionally been treated as the base of the Jaagarahu Stage (Aaloe 1960, 1970). The basal surface of the Muhu Formation bears locally signs of intertidal erosion and channelling, for example, in the sections of Üügu and Pulli cliffs (see Kaljo \& H. Nestor 1990, p. 159). Taking the above into account, we preferred the lithological boundary at $127.4 \mathrm{~m}$ to the cyclostratigraphical boundary at $123.4 \mathrm{~m}$.

The Lower Beds of the Riksu Formation (120.3-127.4 m) represent the most calcareous, thick interval of limestones in the Riksu Formation. The low-rank minicyclicity is poorly expressed. Within this calcareous interval a vague upward trend from wackestone with thicker marly intercalations to packstone with thinner films of marlstone is observable towards a sharp, rugged, pyritized erosional surface at a depth of $123.4 \mathrm{~m}$. From this surface upwards the carbonate/clay ratio decreases gradually. This prominent surface is considered as the junction of mesocyclites II and III and resembles a similar break in the carbonate deposition recognized by Riding \& Watts (1991) in the Gotland succession at the boundary of the Högklint and Tofta (Kopparsvik) beds. The cyclicity type changes more distinctly above a series of rugged discontinuity surfaces at 120.3-121.2 m, considered as the top of the Lower Riksu Beds.

The rest part of the Riksu Formation, i.e. the Middle and Upper beds (mesocycles III and IV), is characterized by a complicated, multistage cyclicity, formed by meso-, submeso-, mini-, and subminicyclites (see Fig. 3), the minicyclite being the basic rank in cyclicity. In an ideal case a minicyclite consists of three parts. The basal part is commonly represented by a nodular, bioturbated, micritic or biomicritic limestone (mainly wackestone) with characteristic stout burrows fringed by dispersed pyrite halo. The middle portion consists of an up to $50 \mathrm{~cm}$ thick marlstone layer. The upper part consists of nodular to seminodular (knobbybedded) biomicritic limestone (prevailingly packstone), but instead of bioturbation, pyritized bio- and lithoclasts, tempestite intercalations, and discontinuity surfaces are common. Different parts of a minicyclite are rather unevenly developed depending on its position in the higher-rank cyclites.

Within the minicyclites an obscure, still lower-rank cyclicity is recognizable (Fig. 3). It is expressed in a small-scale change in the lithological trend, mostly connected with discontinuity surfaces.

Minicyclites group into two mesocyclites (III and IV, Fig. 2) corresponding to the Middle and Upper beds of the Riksu Formation, respectively. Both mesocyclites can be subdivided into four submesocyclites (Fig. 3). All three elements of a minicyclite are well developed only in two lower submesocyclites of mesocyclite III (in the Middle Beds of the Riksu Formation at 107.7-120.3 m). In other cases the lower or the middle part of a minicyclite may be reduced or totally lacking. As a rule, the lower, bioturbated part of a minicyclite is better developed in the lower submesocyclite of both mesocyclites, the middle, marly part - in the middle submesocyclites, and the upper, packstone part - in the upper and topmost submesocyclites. This suggests a general deepening-shallowing (transgressiveregressive) pattern of both mesocyclites, III and IV. Facies differences between 
submesocyclites are sharper in mesocyclite III (Middle Riksu Beds). It means that the amplitude of cyclic changes (sea level fluctuation, intensity of the influx of terrigenous material) was greater during the deposition of the Middle Beds of the Riksu Formation. The lower, and especially the middle submesocyclites of the Middle Riksu Beds contain the largest amount of clayish material typical of the outer part of the open shelf, while the upper and topmost submesocyclites contain numerous discontinuity surfaces, fine-grained storm-layers (tempestites), rounded, pyritized bio- and lithoclasts which are characteristic of the inner part of the open shelf. The shallowest-water deposits occur at the top of the Middle Riksu Beds. They are represented by dolomicrites of lagoonal origin and are capped by an erosional surface with mudcracks. The Upper Riksu Beds, having deposited in more stable settings, are less changeable, but in general these are of a shallowerwater character.

The shallowing-upward trend of development continued in the overlying tongue of the Jaagarahu Formation which is represented by mesocyclites $\mathrm{V}$ and VI. They contain bioclastic grainstones of the second (open shelf) facies zone in their lower part and dolomicrites of the first (lagoonal) facies zone in the upper part. It means that the cycle type changed clearly at the upper boundary of the Riksu Formation although the general, regressive pattern remained the same.

The intricate, multistage cyclicity in the Riksu Formation can be best explained by variations in solar radiation, caused by cyclic changes in the Earth's axial and orbital parameters known as Milankovitch cycles. These variations cause expansion and contraction of continental glaciers, leading to sea level fluctuation and change in sediment input (Imbrie \& Imbrie 1979). Four main types of the Milankovitch cycles have been established lasting about 23, 41, 100, and 400 thousands years (Ka).

In order to estimate the approximate duration of the Riksu sedimentation cycles, different categories of cyclites were counted up. Two and a half mesocyclites, 10 submesocyclites, 27 minicyclites, and 52 subminicyclites were established (see Fig. 3). (These numbers are quite provisional because several difficulties arose in the recognition and estimation of the rank of each cyclite boundary.) The stratigraphical range of the Riksu Formation roughly corresponds to or somewhat exceeds the range of the Cyrtograptus perneri-C. rigidus standard graptolite Biozone (see H. Nestor 1995a). The average duration of a Wenlock standard graptolite biozone is about one million years $(1 \mathrm{Ma})$, following from the number of the standard zones (6 or 7), and duration of the Wenlock Epoch (6-7 Ma). In such a case each Riksu mesocycle might last about $400 \mathrm{Ka}$ and submesocycle about $100 \mathrm{Ka}$, corresponding to the duration of the Milankovitch cycles caused by the excentricity of the Earth's orbit. The calculated duration of a minicycle is approximately $37 \mathrm{Ka}$ and of the subminicycle $19 \mathrm{Ka}$. These values are close to the duration of the Milankovitch cycles arising from the obliquity and precession of the Earth's axis, respectively.

The multistage cyclicity characterizing the Riksu Formation is best expressed in the sediments of the open shelf facies zone, while in shallower-water sediments the lower-rank minicycles are shadowed by more discontinuous sedimentation 
and intensive reworking of deposits in the high-energy environment. On the other hand, in deeper-water facies the smaller-scale fluctuations of sea level are not reflected in the sediment record.

\section{DISTRIBUTION OF FOSSILS}

Six taxonomic groups were studied: chitinozoans, conodonts, vertebrates, stromatoporoids, tabulate corals, and brachiopods.

\section{Chitinozoans}

Conodonts and chitinozoans were identified from 92 samples covering $130 \mathrm{~m}$ of the middle Wenlock to middle Ludlow sequence. The average weight of the samples was $700-1600 \mathrm{~g}$.

The assemblage of chitinozoans is the most diverse and abundant in the Jaani and the lower part of the Jaagarahu stages. The succession begins with the uppermost part of the lower Wenlock chitinozoan Interzone IV, established between the Margachitina margaritana and Conochitina mamilla biozones (V. Nestor 1994), and is characterized by overlapping ranges of Conochitina proboscifera Eisenack and Margachitina margaritana (Eisenack) without Angochitina longicollis Eisenack (Fig. 4). The C. mamilla Biozone with abundant Conochitina claviformis and C. mamilla Laufeld occurs in the interval of 145.4-148.7 m. A remarkable event is the replacement of the dominant species Conochitina proboscifera Eisenack by $C$. claviformis Eisenack at $149.6 \mathrm{~m}$ with some overlap of ranges. In outcrops of northern Saaremaa this event level corresponds to the boundary of the Mustjala and Ninase members of the Jaani Formation.

The Conochitina mamilla Biozone is followed by the Conochitina tuba Biozone. The appearance of Ancyrochitina paulaspina Nestor at $145.4 \mathrm{~m}$, Calpichitina acollaris (Eisenack) and Ancyrochitina gutnica Laufeld at $141.5 \mathrm{~m}$, and Conochitina tuba Eisenack at $140.0 \mathrm{~m}$ shows that the base of the C. tuba Biozone lies approximately at a level of $145 \mathrm{~m}$ within the Ninase Member. The C. tuba Biozone with Calpichitina acollaris (123.1-141.5 m) ranges from the upper half of the Ninase Member to the Lower Riksu Beds. On Gotland Island the C. mamilla and C. tuba biozones correlate with units a-c of the Högklint Beds (Laufeld 1974; V. Nestor \& Einasto 1997).

In the lowermost $10 \mathrm{~m}$ of the Riksu Formation, the species characteristic of the Jaani Stage still occur, with predominance of Conochitina claviformis. Cingulochitina cingulata (Eisenack), the index species of the next biozone, occurring in the lowermost part of the Jamaja Formation of the Jaagarahu Stage, is missing in the Riksu core. However, other species of the Cingulochitina cingulata

Biozone, Clathrochitina clathrata Eisenack (112.5-117.7 m) and Ramochitina martinssoni (Laufeld) $(116.5 \mathrm{~m})$, are found in the lower part of the Middle Riksu Beds. 


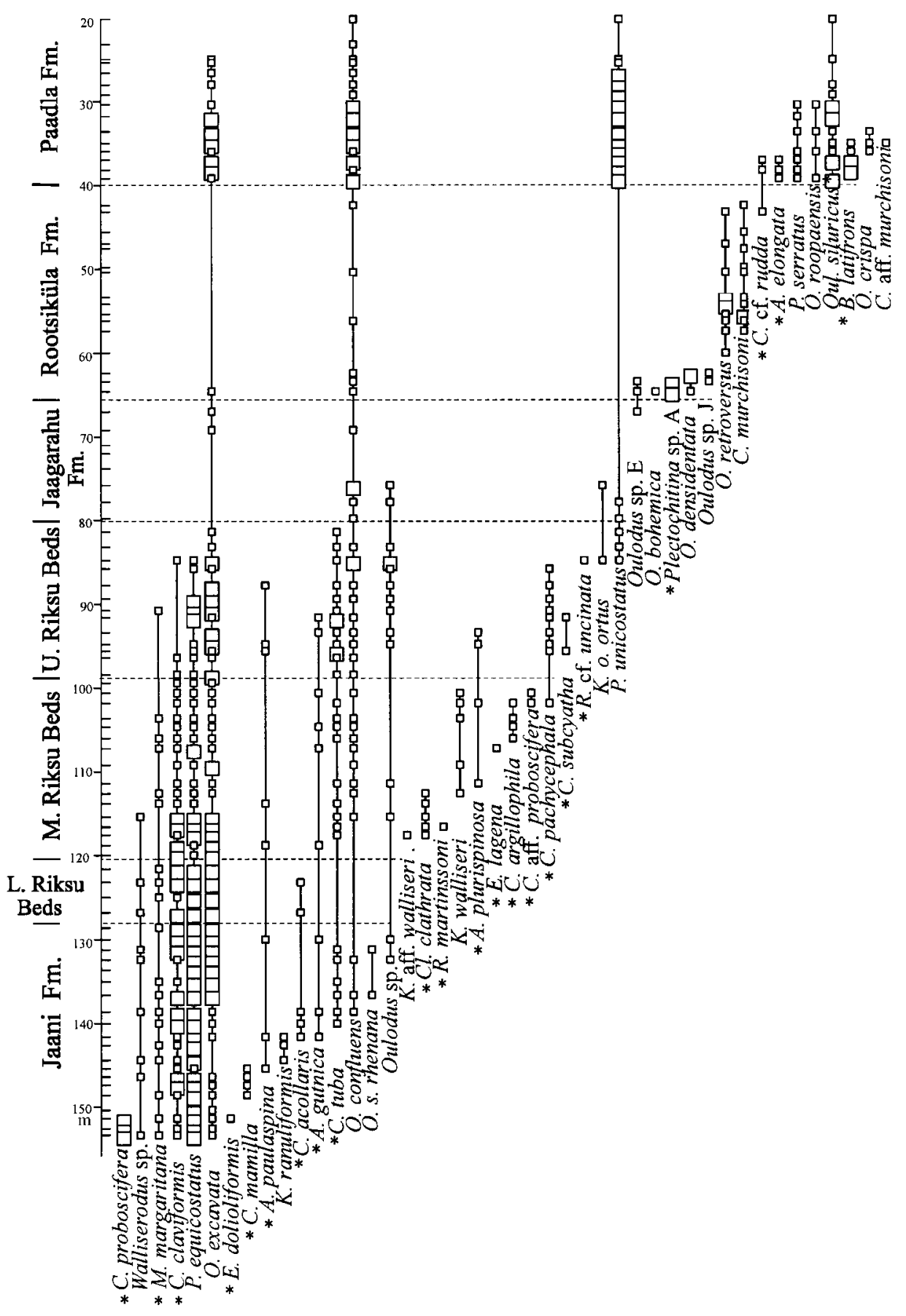

Fig. 4. Range chart of chitinozoans and conodonts of the Riksu core section. The names of the chitinozoan species are designated with an asterisk. Abbreviations of generic names see in text. Minute square - rare occurrence; bigger square - abundant occurrence. U, Upper; L, Lower; M, Middle. 
Eisenackitina lagena (Eisenack), the index species of the next biozone, was found from only one sample $(107.1 \mathrm{~m})$, but the associated species Conochitina argillophila Laufeld is present in some more samples (102-106 m). This enables us to distinguish also the E. lagena Biozone approximately in the interval of 102-108 $\mathrm{m}$ in the Middle Beds of the Riksu Formation.

Conochitina pachycephala Eisenack, along with Conochitina aff. proboscifera Eisenack, appears in the upper part of the Middle Riksu Beds, at a depth of $101.8 \mathrm{~m}$, defining the lower boundary of the $C$. pachycephala Biozone.

The appearance of Conochitina subcyatha Nestor at $95.5 \mathrm{~m}$ determines the base of the C. subcyatha Biozone in the Upper Beds of the Riksu Formation. The most important associated species are here Conochitina tuba, C. pachycephala, and Ancyrochitina plurispinosa Nestor. Approximately at the same level, Conochitina claviformis is replaced by another dominant $-C$. tuba. Upwards in the sequence the assemblage of chitinozoans becomes poorer and Ramochitina cf. uncinata (Laufeld) at $84.7 \mathrm{~m}$ is the only new element recorded from the uppermost part of the Riksu Formation.

Thus, four chitinozoan biozones from Cingulochitina cingulata to Conochitina subcyatha are represented in the Middle and Upper Beds of the Riksu Formation. These correspond to the whole sequence of the Jamaja Formation in the Ohesaare core, as well as to units $\mathrm{d}-\mathrm{g}$ of the Slite Beds and Pentamerus gotlandicus Beds on Gotland (Laufeld 1974; V. Nestor \& Einasto 1997).

The last two chitinozoan biozones of the Wenlock succession, Conochitina cribrosa Nestor and Sphaerochitina indecora Nestor, occurring in the Sõrve Formation of the Ohesaare and Ruhnu sections, were not established in the Riksu core. The corresponding beds are probably missing or partly correlate with dolostones and dolomitic limestones of the tongue of the Jaagarahu Formation, which are barren of chitinozoans.

In the Rootsiküla Formation chitinozoans are found only in a few samples from the Viita Beds (Plectochitina sp. A at 63.4-64.6 m), and from the Soeginina Beds (Conochitina cf. rudda Sutherland at $43.2 \mathrm{~m}$ ). The latter species was first described from the Ludlow type area (Sutherland 1994), where it appeared at the top of the Much Wenlock Limestone, $3.5 \mathrm{~m}$ below the base of the Ludlow Series but was the most common in the Neodiversograptus nilssoni graptolite Biozone interval.

In the lower part of the Paadla Formation, in the Sauvere Beds there occurs a typical Ludlow assemblage of chitinozoans (V. Nestor 1982) represented by numerous Belonechitina latifrons (Eisenack) and Angochitina elongata Eisenack.

\section{Conodonts}

The conodont succession in the Riksu drill core represents a gradual replacement of deeper-water biofacies in the Jaani Stage by shallower-water biofacies in the Rootsiküla and Paadla stages. The conodont alteration index (CAI) is 1. 
The lower part of the section, including the Mustjala, Ninase, and Paramaja members and the Riksu Formation, is characterized by the continuous ranges of Ozarkodina excavata (Branson \& Mehl) and Panderodus equicostatus (Rhodes) (Fig. 4). The former species is particularly abundant in the interval of about 115$140 \mathrm{~m}$ corresponding to the upper part of the Jaani Formation and the lower part of the Riksu Formation. The lowermost zonal species in the Riksu section is Kockelella ranuliformis (Walliser) found in the Ninase Member (141.5-144.5 m). The occurrence of Ozarkodina sagitta rhenana (Walliser) in the interval of 131.1-144.4 $\mathrm{m}$ defines the next standard conodont zone - the O. s. rhenana Biozone occurring in the Ninase and Paramaja members. The distribution of these zonal species is quite similar in the outcrops of northern Saaremaa and in the drill cores of southern Saaremaa. In the sample at a depth of $117.6 \mathrm{~m}$ a single complete Pa element of Kockelella aff. walliseri (Helfrich) is found which differs from typical specimens by a bifurcated lateral denticle row on one side of the platform. This occurrence marks the lower boundary of the $K$. walliseri Biozone. In the Riksu section occurrences of typical $K$. walliseri are limited to the Middle Riksu Beds (100.6-111.3 m). It is noteworthy that in the Ohesaare drill core K. walliseri (= Spathognathodus corpulentus in Viira 1975) was found in the interval of 256.9-294.0 m which corresponds to the lower half of the Jamaja Formation. K. walliseri has also been found from the Kaugatuma drill core $(143.8-161.5 \mathrm{~m})$ and the Sepise and Kurevere outcrops. The specimens from the Sepise and Kurevere outcrops, belonging to the Maasi Beds of the Jaagarahu Formation, are very similar to those from the Slite unit $d$ at Store Myre and Katrinenlund 2 on Gotland (Jeppsson et al. 1994).

The Upper Riksu Beds almost lack zonal species of conodonts. Only Kockelella ortus ortus (Walliser) (= K. absidata in Jeppsson et al. 1994, fig. 5) is recorded from their uppermost part in the sample at $84.7 \mathrm{~m}$. At the same level Panderodus equicostatus is replaced by P. unicostatus (Branson \& Mehl). Another specimen of $K . o$. ortus is identified from the overlying tongue of the Jaagarahu Formation at a depth of $75.8 \mathrm{~m}$. These two findings determine the occurrence of the K. o. ortus Biozone, established by Jeppsson (1997) in the upper part of the Slite Beds on Gotland. A $15 \mathrm{~m}$ interval of indeterminancy occurs between the local ranges of $K$. walliseri and $K$. o. ortus in the Riksu section. The zonal conodont Ozarkodina sagitta sagitta (Walliser) is not found in the Riksu core probably due to a hiatus between the Jaagurahu and Rootsiküla formations.

The index species of the next conodont zone Ozarkodina bohemica bohemica (Walliser) is determined only in the sample at $64.6 \mathrm{~m}$, in the lowermost Rootsiküla Formation, which makes it impossible to establish its real range. Another species, Ozarkodina denticulata (Viira), usually characteristic of the Viita Beds, is more numerous. In the Vesiku and Soeginina beds, shallow-water conodonts Ctenognathodus murchisoni (Pander) and Ozarkodina retroversus (Viira) dominate.

A sharp change in the conodont succession takes place at the base of the Paadla Formation, mainly due to a stratigraphical gap and change of facies. The conodont fauna in the Paadla Formation is diverse and abundant. The most 
common species are Ozarkodina confluens (Branson \& Mehl), Ozarkodina excavata (Branson \& Mehl), and Oulodus siluricus (Branson \& Mehl). The zonal species Ozarkodina crispa (Walliser) is represented in three samples (in the interval of 33.5-36.0 m) by morphotypes $\alpha_{2}$ and $\alpha_{3}$ (Viira \& Aldridge 1998). Besides, rare specimens of the shallow-water species Ozarkodina roopaensis Viira and more numerous specimens of Panderodus serratus Rexroad are also identified in the Sauvere Beds.

In conclusion, the Riksu core section exhibits the standard conodont zones $K$. ranuliformis, $O$. s. rhenana, $K$. walliseri, $K$. o. ortus, and $O$. b. bohemica in the Wenlock and O.crispa in the Ludlow. The O. sagitta sagitta Biozone has not been established between the K. o. ortus and $O$. b. bohemica biozones, obviously due to a subregional hiatus between the Jaagarahu and Rootsiküla stages (V. Nestor \& H. Nestor 1991). This hiatus occurs also in eastern Gotland between the Slite and Halla beds (Calner 1999; Calner \& Säll 1999), but is lacking in the continuous graptolitic sections of the Baltic Syneclise (Paškevičius et al. 1995). The Riksu Formation, except the Lower Beds which do not contain zonal species, corresponds to the K. walliseri and partly to the K. o. ortus biozones. More precisely, the Middle Beds of the Riksu Formation correspond well to the $K$. walliseri Biozone and the uppermost part of the Riksu Formation to the $K$. o. ortus Biozone.

The correlation with Gotland shows that the Middle and Upper Riksu beds correspond to the Slite Beds units d-g (Jeppsson et al. 1994; Jeppsson 1997). The exact correlation with different local sections of the Jaagarahu Stage on Saaremaa is rather difficult because of unfavourable facies. The biostratigraphically valuable species of kockelellids are usually absent in the Jaagarahu Formation, which complicates its correlation with the Riksu Formation.

\section{Vertebrates}

Vertebrates are represented in the Riksu drill core by the scales of thelodonts and shield fragments of osteostracans. Three distinctive assemblages of agnathans are recognized in the Riksu and Rootsiküla formations (Wenlock) and in the Paadla Formation (Ludlow).

The lowest thelodont species is Loganellia grossi Fredholm, identified with some doubt in the interval of 100.6-100.7 m, i.e. in the upper part of the Middle Riksu Beds (Fig. 5). In the Upper Riksu Beds, at 89.25-89.40 m, the typical L. grossi scales are found already together with those of Loganellia einari Märss. The latter species ranges as high as $84.7-84.8 \mathrm{~m}$. Consequently, the junction of the L. grossi and L. einari biozones occurs in the interval of 84.7-100.7 m, whereas both zones remain within the limits of the Riksu Formation.

In the area of the distribution of the Jaagarahu Formation, the L. grossi Biozone coincides with the upper part of the Maasi Beds and with the lower half of the Tagavere Beds; the L. einari Biozone has been established from the upper half of the Tagavere Beds (Märss 1996). On Gotland Island, L. grossi type 


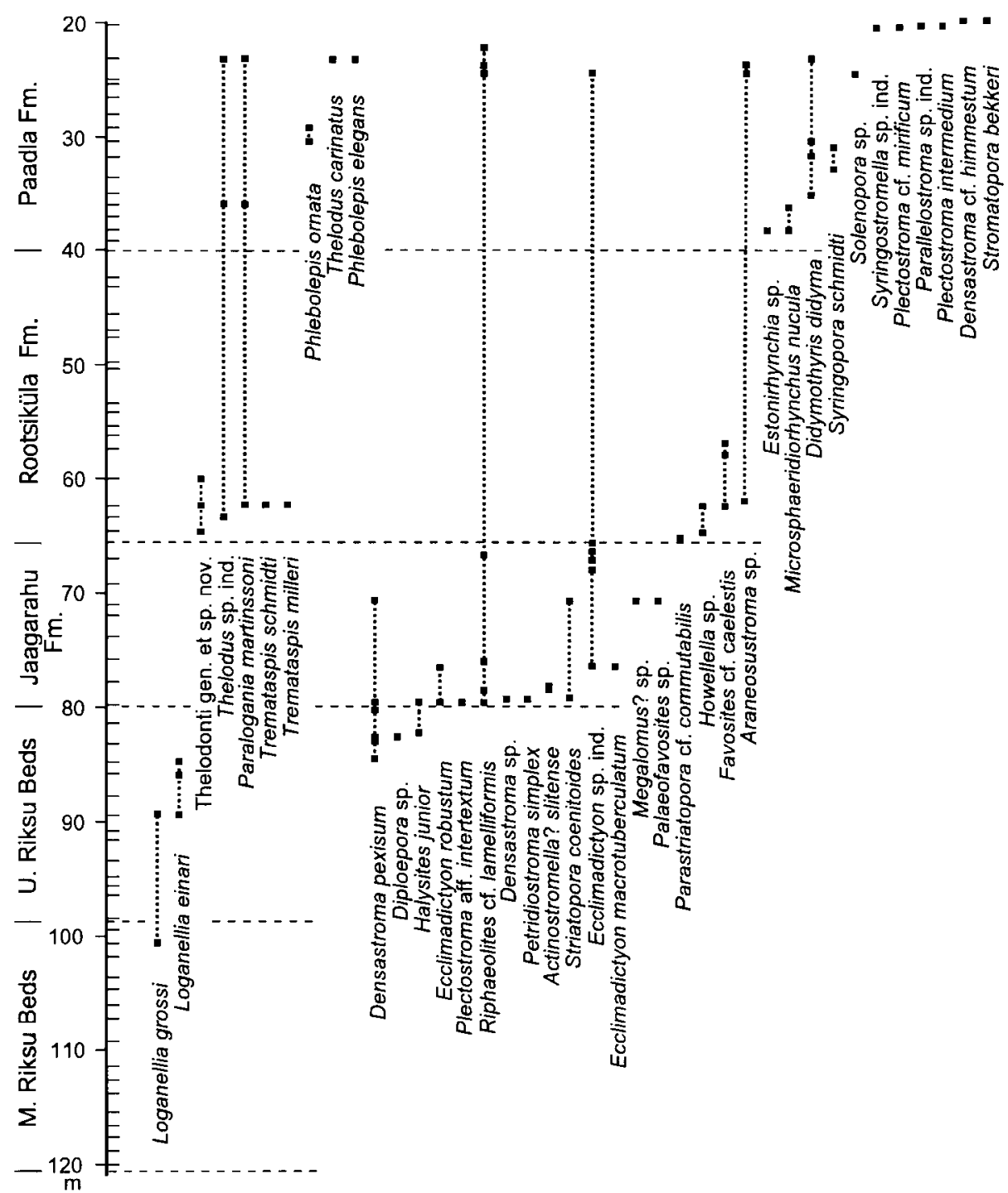

Fig. 5. Range chart of vertebrates, stromatoporoids, and other macrofossils of the Riksu core section. U, Upper; M, Middle.

material comes from unit $g$ of the Slite Beds, whereas the L. einari Biozone occurs in the uppermost Slite Beds.

The lower part of the Viita Beds in the interval of $60.2-64.8 \mathrm{~m}$ contains an assemblage of the thelodonts Thelodonti gen. et sp. nov. and Paralogania martinssoni (Gross), as well as the osteostracans Tremataspis schmidti Rohon and Tremataspis milleri Patten. The appearance of $P$. martinssoni marks the base of the $P$. martinssoni Biozone which ranges throughout the Rootsiküla Formation into the Sauvere Beds of the Paadla Formation up to the beginning of the 
next, Phlebolepis ornata Biozone. The vertebrate assemblage characteristic of the P. martinssoni Biozone is represented in the Viita and Vesiku outcrops. On Gotland, the biozone ranges from the Halla to Hemse beds (Fredholm 1990).

In the Paadla Formation vertebrates occur in three levels. A sample from a depth of $36.0 \mathrm{~m}$ contains few pyritized and etched scales of Thelodus sp. ind. and Paralogania martinssoni indicating the P. martinssoni Biozone. Two samples from the interval of 29.15-30.45 m yield only spiny scales of Phlebolepis ornata Märss showing the presence of the Phlebolepis ornata Biozone (Märss 1986) characteristic of the Sauvere Beds of the Paadla Formation. The findings on Saaremaa come mostly from the rocks of the restricted shelf facies. On Gotland scarce $P$. ornata have been identified from the Hemse Limestone units $\mathrm{b}$ and $\mathrm{c}$ and from the Hemse NW marls, which by Fredholm (1988) are not older than the middle Elton and probably not younger than the Bringewoodian.

In the topmost sample of the Riksu section, collected at $23.10-23.30 \mathrm{~m}$, Thelodus carinatus (Pander) and Phlebolepis elegans Pander appear and occur together with Thelodus sp. ind. and Paralogania martinssoni passing over from the lowerlying strata. Articulated specimens of Phlebolepis elegans have been previously collected from the lagoonal dolomites of the Himmiste Beds of the Paadla Formation. On Gotland P. elegans has been found in the Hemse Limestone units c (uppermost part), d, and e, and in the Hemse NW and SE marls (Fredholm 1988).

Thus, in the Riksu section only Phlebolepis ornata and Phlebolepis elegans and the corresponding biozones have been established in the Paadla Formation. The higher, Andreolepis hedei Biozone, which characterizes the upper part of the Uduvere Beds of the Paadla Formation, is not detected as the bedrock sequence in the Riksu borehole begins with the lowermost Uduvere strata.

\section{Macrofossils}

Macrofossils could be identified only in the upper half of the Riksu drill core beginning from the topmost layers (80.4-84.5 m) of the Riksu Formation (Fig. 5) from where a single stromatoporoid species Densastroma pexisum (Yavorsky) was found. This species has a rather wide stratigraphical and ecological range, but is most frequent in the distal part of the open shelf facies. It is recorded from the Jaani and Jaagarahu formations on Saaremaa, and from the Visby and Slite marls on Gotland (H. Nestor 1999). The distribution of the tabulate corals Halysites junior Klaamann and Diploepora sp. is almost similar except that their range is restricted to the Jaagarahu Formation in Estonia and to the Slite Beds on Gotland.

Corals and stromatoporoids are quite common in the overlying tongue of the Jaagarahu Formation, especially in its lower part. Besides D. pexisum and H. junior, there occur stromatoporoids Ecclimadictyon robustum Nestor, Petridiostroma simplex (Nestor), Actinostromella? slitensis Mori, and Ecclimadictyon macrotuberculatum (Riabinin); and tabulates Riphaeolites lamelliformis Klaamann and 
Striatopora coenitoides Klaamann. They all are quite common in the Jaagarahu Formation (particularly in the Maasi Beds) in Estonia, and in the Slite Beds on Gotland (H. Nestor 1999). These species are characteristic of the shoal and open shelf facies belts, except for Riphaeolites lamelliformis which has previously been identified only from lagoonal dolomites of the Tagavere Beds forming the upper part of the Jaagarahu Formation in northern Saaremaa (Klaamann 1986).

The Rootsiküla Formation of the Riksu section is poor in macrofossils. Only the Viita and lowermost Kuusnõmme beds contain the tabulates Parastriatopora cf. commutabilis Klaamann, Favosites cf. caelestis Klaamann, a stromatoporoid Araneosustroma sp., and a brachiopod Howellella sp. which are typical representatives of the lagoonal Benthic Assemblage 1 according to Boucot (1975).

In the lower part of the Paadla Formation (Sauvere Beds), only rare specimens of the brachiopods Didymothyris didyma (Dalman), Microsphaeridiorhynchus nucula (Sowerby), and Estonirhynchia sp.; and the tabulate coral Syringopora schmidti Tchernychev are found. In the Himmiste Beds the lagoonal community of Riphaeolites lamelliformis Klaamann and Araneosustroma sp. reappears. A rather rich stromatoporoid fauna consisting of Plectostroma intermedium (Yavorsky), Densastroma cf. himmestum (Riabinin), Stromatopora bekkeri Nestor, and Plectostroma cf. mirificum Nestor occurs in the Uduvere Beds. This stromatoporoid association is characteristic also of the Hemse Beds on Gotland (H. Nestor 1999).

To sum up, macrofossils were identified only from the upper portion of the Riksu section (topmost Riksu, Jaagarahu, Rootsiküla, and Paadla formations). The species common in the same units in the outcrop belt on northern Saaremaa were found. The lower part of the Riksu core section (Riksu and Jaani formations) yielded no identifiable macrofossils.

\section{CORRELATION OF THE RIKSU FORMATION}

As mentioned in the introduction, the Riksu Formation is replaced by the Jaagarahu and Muhu formations in a northerly direction and grades laterally into the Jamaja Formation towards the south (Fig. 6). A recent study of a section of the Slite Beds at Slitebrottet 2 on eastern Gotland (V. Nestor \& Einasto 1997), as well as the sediment log of the Filehajdar section by Jacobsson (1997), revealed great facies similarity and analogous cyclicity of the Riksu Formation and the Slite Marl s.s. in their type areas. Comparison of chitinozoan successions of both units confirmed their approximate contemporaneity.

The biostratigraphical correlation is the closest between the Riksu and Jamaja Formations. The base of the Jamaja Formation coincides with the base of the Kockelella walliseri conodont Biozone and the Cingulochitina cingulata chitinozoan Biozone. The species characteristic of these biozones Kockelella aff. walliseri, Clathrochitina clathrata, and Ramochitina martinssoni appear about 


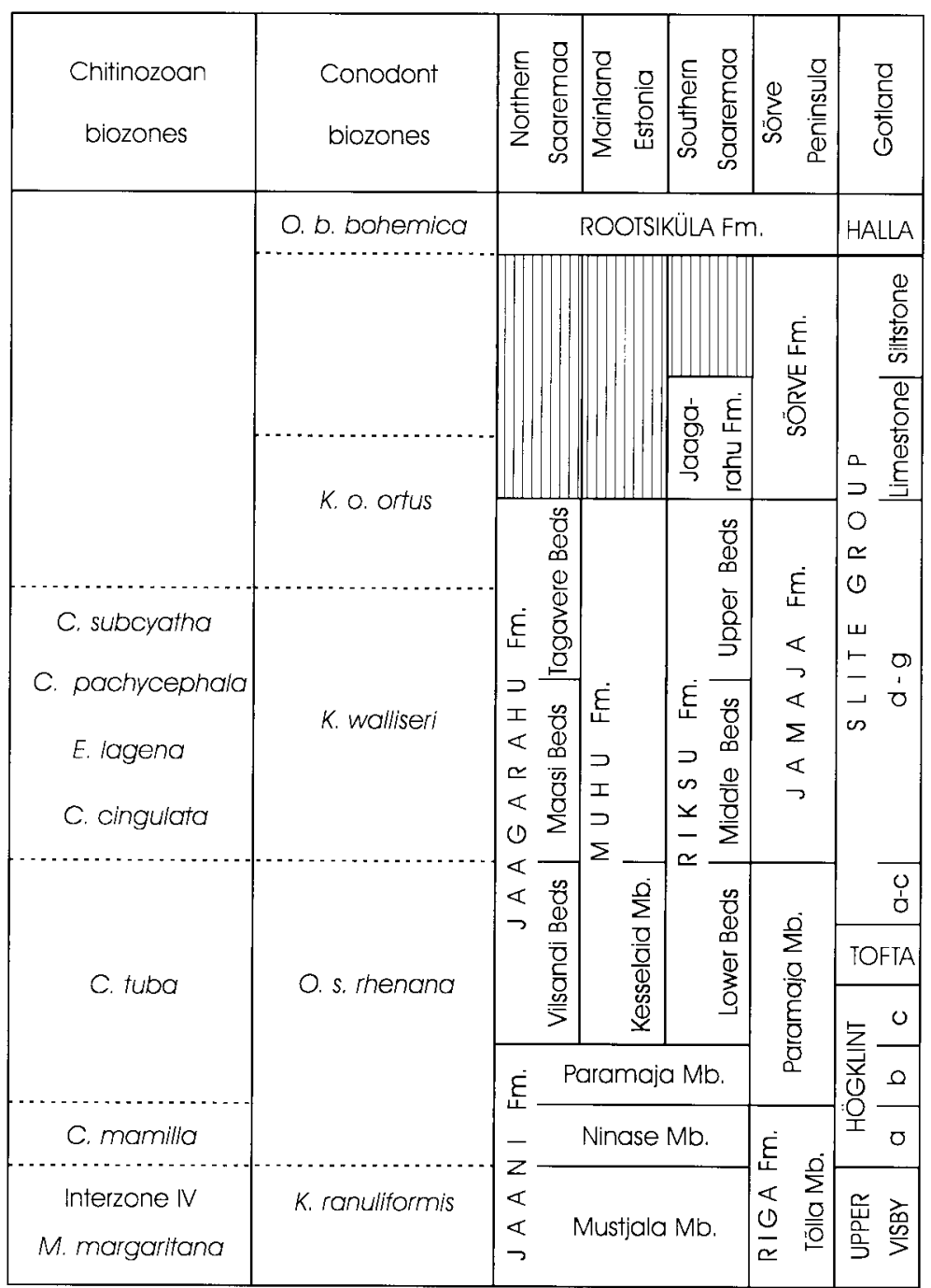

Fig. 6. Correlation of the Riksu Formation, and zonal successions of chitinozoans and conodonts in the Riksu core.

2.5-4.0 m above the base of the Middle Riksu Beds (Fig. 4). The last record of Calpichitina acollaris, a common species in the Conochitina tuba chitinozoan Biozone, about $2 \mathrm{~m}$ below the base of the Middle Riksu Beds, enables correlation of the contact between the Lower and Middle Riksu beds with the base of the Jamaja Formation. The base of the Riksu Formation lies in the stratotype section about $6 \mathrm{~m}$ lower, within the Conochitina tuba Biozone.

Above the Cingulochitina cingulata Biozone, zonal species of the Eisenackitina lagena, Conochitina pachycephala, and Conochitina subcyatha biozones were 
established in the Riksu section in the Jamaja Formation (Fig. 6). However, in the Ohesaare drill core the last species ranges over the boundary of the Jamaja and Sorve formations, whereas in the Riksu section it is confined to the lower half of the Upper Riksu Beds. It is hard to decide whether the top of the Riksu Formation lies stratigraphically higher than that of the Jamaja Formation, or the absence of C. subcyatha might be explained by the scarcity of chitinozoans in the uppermost part of the Riksu Formation.

The correlation of the Riksu Formation with shallow-water sequences of the Jaagarahu and Muhu formations is much more complicated since the latter are almost devoid of microfossils. The reef-related rocks of the basal Jaagarahu (Vilsandi Beds) and Muhu (Kesselaid Member) formations, barren of microfossils, are mostly underlain by the marlstones of the Paramaja Member of the Jaani Formation which contain chitinozoans of the Conochitina tuba Biozone, including Calpichitina acollaris (V. Nestor 1994). In the Riksu drill core the local range of Calpichitina acollaris is much wider, from the middle of the Ninase Member to the middle of the Lower Riksu Beds. The latter form the most calcareous unit in the section, which is litho- and cyclostratigraphically correlatable with the Vilsandi Beds and Kesselaid Member of the Jaagarahu and Muhu formations, respectively. Rare, scattered specimens of the conodont Kockelella walliseri and the thelodont Loganellia grossi have been identified from the overlying Maasi Beds of the Jaagarahu Formation. Both species occur also in the Middle Beds of the Riksu Formation. This allows lithostratigraphical correlation of these beds forming the most argillaceous subunits in the middle of the Jaagarahu and Riksu formations.

The Upper Beds of the Riksu Formation contain a zonal thelodont Loganellia einari which occurs also in the uppermost, Tagavere Beds of the Jaagarahu Formation. However, the biostratigraphical data are too scanty for more exact correlation of the subunit boundaries of the Riksu and Jaagarahu formations. Nevertheless, the stratigraphical range of the Riksu Formation more or less corresponds to the generally accepted range of the Jaagarahu Formation in its type area, northern Saaremaa. In the present paper a problematic interval of the Riksu section (65.7-80.4 m) above the Riksu Formation is tentatively included in the Jaagarahu Formation (Fig. 6). Actually, it may wholly or partly correspond to an extensive hiatus above the Tagavere Beds of the Jaagarahu Formation in northern Saaremaa.

The Slite Group is an approximate temporal counterpart of the Riksu Formation in the sequence of Gotland, but the boundaries of these units do not coincide. The guide fossils of the Cingulochitina cingulata, Eisenackitina lagena, and Conochitina pachycephala chitinozoan biozones have been recognized in the Slite units $\mathrm{d}-\mathrm{g}$ (= Slite Marl s.s.) and within the Pentamerus gotlandicus Layer. In the Riksu section these biozones correspond mainly to the Middle Riksu Beds, containing also a zonal conodont Kockelella walliseri common in the Slite unit d. The Conochitina subcyatha Biozone, characteristic of the Upper Riksu Beds, is not recognized in the Gotland sequence (V. Nestor 1994), obviously due to unfavour- 
able ecological conditions for chitinozoans in the uppermost, reef-related limestones of the Slite Beds.

The Lower Beds of the Riksu Formation represent the carbonate maximum in the sequence and contain very few specific taxa of microfossils. Only rare findings of Calpichitina acollaris are noteworthy. In the Gotland sequence, a similar micropalaeontological interregnum, accompanied by a carbonate maximum, characterizes the upper part of the Högklint unit c, Tofta Beds (= Kopparsvik Formation by Riding \& Watts 1991), and the lowermost layers (a, b, and c) of the Slite Beds. The few microfossils discovered in this interval include the chitinozoans Calpichitina acollaris (Högklint unit c) and Conochitina tuba (Slite unit c) (Laufeld 1974) characteristic of the Conochitina tuba Biozone. In the Riksu section this biozone ranges from the Paramaja Member of the Jaani Formation to the Lower Beds of the Riksu Formation. This allows us to correlate the carbonate maxima in the Lower Riksu Beds and upper Högklint-lowermost Slite beds. In the northern Saaremaa sections the carbonate maximum coincides with the Vilsandi Beds of the Jaagarahu Formation consisting of reef limestones with the stromatoporoid Vikingia tenuis (Nestor) as the main frame builder. The same species occurs abundantly in the Högklint reefs and the overlying Tofta limestones. This suggests that an extensive early Wenlock (Högklint, Jaagarahu) reef formation commenced almost contemporaneously along the margins of the Baltic Basin in Estonia and the Gotland area (H. Nestor 1995b). Basinward it was replaced by the accumulation of large amounts of bioclastic material which formed comparatively pure limestones of the Lower Riksu Beds.

In summary, the currently used lower boundary of the Riksu Formation (H. Nestor 1997) roughly correlates with the traditional base of the Jaagarahu Stage (Aaloe 1960, 1970), that is, with the lower boundary of the Jaagarahu and Muhu formations. It lies somewhere within the Högklint Formation, but is certainly lower than the palaeontologically well-founded base of the Jamaja Formation which obviously coincides with the junction of the Lower and Middle Riksu Beds. The upper boundary of the Riksu Formation lies near the top of the Jamaja, Jaagarahu, and Slite formations, but exact correlation is complicated due to insufficient micropalaeontological data from the uppermost part of these formations and the overlying strata.

\section{CONCLUSIONS}

The Riksu Formation represents a lithostratigraphical unit of the open shelf biomicritic calcareous deposits of the Jaagarahu Regional Stage, grading laterally into the Jaagarahu and Muhu formations towards the north and into the Jamaja Formation towards the south. On Gotland Island it roughly corresponds to the upper Högklint, Tofta, and Slite beds. The lower boundary of the Riksu Formation is positioned at the traditionally accepted base of the Jaagarahu Regional Stage 
and Formation, but it lies lower than the base of the Jamaja Formation and the Slite Beds.

The multistage cyclicity in the Riksu Formation was probably induced by variations in solar radiation, caused by the periodical changes in the Earth's orbital and axial parameters known as the Milankovitch cycles. A mesocycle and a submesocycle probably correspond to the $400 \mathrm{Ka}$ and $100 \mathrm{Ka}$ Milankovitch cycles conditioned by the eccentricity of the Earth's orbit. A minicycle and a subminicycle approach to the $41 \mathrm{Ka}$ and $23 \mathrm{Ka}$ cycles arising from the obliquity and precession of the Earth's axis.

\section{ACKNOWLEDGEMENTS}

This study was carried out in the Institute of Geology at Tallinn Technical University and was supported by the Estonian Science Foundation (grants Nos. 3749 and 4160). We are grateful to D. Kaljo and M. Calner for the constructive reviews of the paper. The help of K. Ronk with preparation of the figures is acknowledged.

\section{REFERENCES}

Aaloe, A. 1960. Some new researches on the stratigraphy of the Silurian in Estonia. Geol. Inst. Uurimused, 5, 123-141 (in Russian).

Aaloe, A. 1970. Jaani Stage. Jaagarahu Stage. In Silur Éstonii (Kaljo, D., ed.), pp. 243-264. Valgus, Tallinn (in Russian).

Aaloe, A., Kaljo, D., Klaamann, E., Nestor, H. \& Einasto, R. 1976. Stratigraphical classification of the Estonian Silurian. ENSV TA Toim. Keemia Geol., 25, 38-45 (in Russian).

Boucot, A. J. 1975. Evolution and Extinction Rate Controls. Elsevier, Amsterdam.

Calner, M. 1999. Stratigraphy, facies development and depositional dynamics of the Late Wenlock Fröjel Formation, Gotland, Sweden. GFF, 121, 13-24.

Calner, M. \& Säll, E. 1999. Transgressive oolites onlapping a Silurian rocky shoreline unconformity, Gotland, Sweden. GFF, 121, 91-100.

Fredholm, D. 1988. Vertebrate biostratigraphy of the Ludlovian Hemse Beds of Gotland, Sweden. $G F F, 110,237-253$.

Fredholm, D. 1990. Agnathan vertebrates in the Lower Silurian of Gotland, Sweden. GFF, 112, 61-84.

Grigelis, A. A. (ed.). 1978. Resheniya Mezhvedomstvennogo regional'nogo stratigraficheskogo soveshchaniya po razrabotke unifitsirovannykh stratigraficheskikh skhem Pribaltiki, $1976 \mathrm{~g}$. $s$ unifitsirovannymi stratigraficheskimi korrelyatsionnymi tablitsami. LITNIGRI, Leningrad (in Russian).

Imbrie, J. \& Imbrie, K. P. 1979. Ice Ages: Solving the Mystery. Harvard Univ. Pr., Cambridge, Massachusetts.

Jacobsson, M. 1997. Storm deposition on a Silurian prograding carbonate ramp, Slite Beds, Gotland. GFF, 119, 199-206.

Jeppsson, L. 1997. A new latest Telychian, Sheinwoodian and early Homerian (early Silurian) standard conodont zonation. Trans. Roy. Soc. Edinburgh Earth Sci., 88, 91-114.

Jeppsson, L., Viira, V. \& Männik, P. 1994. Silurian conodont-based correlation between Gotland (Sweden) and Saaremaa (Estonia). Geol. Mag., 131, 201-218. 
Kaljo, D. L. (ed.). 1987. Resheniya Mezhvedomstvennogo stratigraficheskogo soveshchaniya po ordoviku i siluru Vostochno-Evropejskoj platformy, $1984 \mathrm{~g}$. s regional'nymi stratigraficheskimi skhemami. VSEGEI, Leningrad (in Russian).

Kaljo, D. \& Nestor, H. (eds.). 1990. Field Meeting Estonia 1990: An Excursion Guidebook. Inst. Geol., Estonian Acad. Sci., Tallinn.

Klaamann, E. 1986. The tabulate communities and biozones of the East Baltic Silurian. In Theory and Practice of Ecostratigraphy (Kaljo, D. \& Klaamann, E., eds.), pp. 80-98. Valgus, Tallinn.

Laufeld, S. 1974. Silurian Chitinozoa from Gotland. Fossils and Strata, 5.

Märss, T. 1986. Silurian Vertebrates of Estonia and West Latvia. Valgus, Tallinn (in Russian).

Märss, T. 1996. Loganellia (Thelodonti, Agnatha) from the Jaagarahu Stage, Wenlock, Estonia. Proc. Estonian Acad. Sci. Geol., 45, 189-202.

Nestor, H. 1993. Catalogue of Silurian Stratigraphic Units and Stratotypes in Estonia and Latvia. Estonian Acad. Sci., Tallinn.

Nestor, H. 1995a. Comments to the modernized Silurian correlation chart of Estonia and Latvia. Geologija, 17, 88-95.

Nestor, H. 1995b. Ordovician and Silurian reefs in the Baltic area. Publ. Serv. Géol. Luxembourg, 29, 39-47.

Nestor, H. 1997. Silurian. In Geology and Mineral Resources of Estonia (Raukas, A. \& Teedumäe, A., eds.), pp. 89-106. Estonian Acad. Publ., Tallinn.

Nestor, H. 1999. Community structure and succession of Baltoscandian early Palaeozoic stromatoporoids. Proc. Estonian Acad. Sci. Geol., 48, 123-139.

Nestor, H. \& Einasto, R. 1977. Facies-sedimentary model of the Silurian Paleobaltic pericontinental basin. In Fatsii i fauna silura Pribaltiki (Kaljo, D., ed.), pp. 89-121. Akad. Nauk ESSR, Tallinn (in Russian).

Nestor, H. \& Einasto, R. 1997. Ordovician and Silurian carbonate sedimentation basin. In Geology and Mineral Resources of Estonia (Raukas, A. \& Teedumäe, A., eds.), pp. 192-204. Estonian Acad. Publ., Tallinn.

Nestor, V. 1982. Correlation of the East Baltic and Gotland Silurian by chitinozoans. In Ecostratigraphy of the East Baltic Silurian (Kaljo, D. \& Klaamann, E., eds.), pp. 89-96. Acad. Sci. ESSR, Tallinn.

Nestor, V. 1984. Zonal distribution of Chitinozoans in the Wenlockian Jaani Stage of Estonia and the problem of its upper boundary. In Stratigrafiya drevnepaleozojskikh otlozhenij Pribaltiki (Männil, R. M. \& Mens, K. A., eds.), pp. 119-127. Akad. Nauk ESSR, Tallinn (in Russian).

Nestor, V. 1994. Early Silurian Chitinozoans of Estonia and North Latvia. Estonian Acad. Publ., Tallinn.

Nestor, V. \& Einasto, R. 1997. Correlation of some Wenlock outcrop sections of Gotland with the Ohesaare section of Saaremaa, Estonia. Proc. Estonian Acad. Sci. Geol., 46, 155-168.

Nestor, V. \& Nestor, H. 1991. Dating of the Wenlock carbonate sequences in Estonia and stratigraphic breaks. Proc. Estonian Acad. Sci. Geol., 40, 50-60.

Paškevičius, J., Lapinskas, P., Brazauskas, A., Musteikis, P. \& Jacyna, J. 1995. Stratigraphic revision of the regional stages of the upper Silurian part in the Baltic Basin. Geologija, 17, 64-87.

Perens, H. 1995. Jaani ja Jaagarahu lademe piirikihtidest Saaremaal. Bull. Geol. Surv. Estonia, 5/1, $12-19$.

Riding, R. \& Watts, N. R. 1991. The lower Wenlock reef sequence of Gotland: facies and lithostratigraphy. GFF, 113, 343-372.

Sutherland, S. J. E. 1994. Ludlow chitinozoans from the type area and adjacent regions. Palaeontogr. Soc. Monogr., 148.

Viira, V. 1975. A new species of Spathognathodus from the Jaani Stage of the East Baltic. ENSV TA Toim. Keemia Geol., 24, 233-236 (in Russian).

Viira, V. \& Aldridge, R. 1998. Upper Wenlock to Lower Přidoli (Silurian) conodont biostratigraphy of Saaremaa, Estonia, and a correlation with Britain. J. Micropalaeontol., 17, 33-50. 


\title{
RIKSU KIHISTU (WENLOCK) STRATOTÜÜPSE LÄBILÕIKE KIRJELDUS, TSÜKLILISUS JA KORRELATSIOON
}

\author{
Heldur NESTOR, Rein EINASTO, Viiu NESTOR, Tiiu MÄRSS ja Viive VIIRA
}

On esitatud Riksu kihistu stratotüüpse puuraugu (Saaremaa) läbilõike esmakirjeldus. Kihistu koosneb tsükliliselt vahelduvatest avašelfi mudalis-detriitsetest lubjakividest ja merglitest, mis põhja suunas asenduvad Jaagarahu ja Muhu kihistu rifilubjakivide ja dolokividega ning lõuna suunas Jamaja kihistu merglitega. Riksu kihistu ajaliseks ja fatsiaalseks analoogiks Gotlandi saarel on Slite kihid. Kihistu alumine piir on ühitatud Jaagarahu lademe traditsioonilise alumise piiriga, mis paikneb aga läbilõikes madalamal kui Jamaja kihistu ning Slite kihtide alumine piir.

\section{ОПИСАНИЕ ТИПОВОГО РАЗРЕЗА РИКСУСКОЙ СВИТЫ (ВЕНЛОК, ЭСТОНИЯ), ЕЕ ЦИКЛИЧНОСТЬ И КОРРЕЛЯЦИЯ}

\author{
Хелдур НЕСТОР, Рейн ЭЙНАСТО, Вийу НЕСТОР, Тийу МЯРСС и \\ Вийве ВИЙРА
}

Описан типовой разрез (о-в Сааремаа) риксуской свиты яагарахуского горизонта, состоящий из циклически чередующихся илисто-детритовых известняков и мергелей открытого шельфа, которые в северном направлении замещаются рифогенными известняками и доломитами яагарахуской и мухуской свит, а к югу - мергелями ямаяской свиты. На о-ве Готланд ее фациальными и временными аналогами являются слои Слите. Нижняя граница риксуской свиты совмещена с традиционным основанием яагарахуского горизонта, которое залегает стратиграфически ниже основания ямаяской свиты и слоев Слите. 